\title{
A longitudinal study of accounting students' ethical judgement making ability
}

\author{
Maisarah Mohamed Saat ${ }^{1}$ \\ Universiti Teknologi Malaysia, Skudai Johor Malaysia \\ Dr. Stacey Porter $^{2 *}$ \\ Dr. Gordon Woodbine ${ }^{3}$
}

School Of Accounting, Curtin University of Technology, Perth, WA 6845

*Corresponding author. Tel: +61 89266 2375; fax: +61 892667196

E-mail addresses: Stacey.Porter@cbs.curtin.edu.au (S. A. Porter), maisarah.mohamedsaat@postgrad.curtin.edu.au (M. M. Saat), Gordon.Woodbine@cbs.curtin.edu.au (G. Woodbine)

${ }^{2}$ Tel : +6189266 2375; fax: +61 892667421

${ }^{3} \mathrm{Tel}: \underline{+61} 892667295 ;$ fax +61892667196 


\title{
A longitudinal study of accounting students' ethical judgement making ability
}

\begin{abstract}
This paper reports the effect of a moral education program on the ethical judgement making ability of university students. The program comprises two forms of intervention: a dedicated ethics course and subsequent practical training. A total of 113 accounting students from six Malaysian universities participated in a longitudinal study including three points of data collection, prior to an ethics course, after an ethics course, and following six-month's practical training. James Rest's short version of the Defining Issues Test (DIT) instrument (Rest, 1986) was employed and p-scores calculated at each data collection point. General Linear Model Repeated Measure analysis was employed to examine the within-subjects effect of the accounting program on ethical judgement making ability. The findings highlight that the accounting program is able to elevate levels of ethical judgement making ability and that practical training contributed significantly to the observed improvement. Results of this study appear to indicate that socialization and interaction with the work environment are significant determinants of improvements in principled reasoning processes.
\end{abstract}

Keywords: ethical judgement making ability, accounting students, ethics education, practical training 


\section{Introduction}

The accounting profession is one group that contributes greatly to the economic well-being of a society. Accountants in public practice are responsible for verifying the transactions that are recorded, validated and reported in accordance with standards (Harding, 1999). To this end, accountants have a duty to protect the public interest, making sure public and private finances are properly managed. The public, in return, has an increasing expectation that members of the accounting profession possess high moral values and act with integrity. Ethics in accounting education is seen as one way of achieving high moral standards and is an essential element in nourishing investor trust, helping to generate sustainable growth, and building confidence in the economy. In this context, accountants can be described as gatekeepers in a business context. Consequently, the call for strengthening ethics education in the accounting profession is intense. The International Federation of Accountants (IFAC) is a global organisation representing the accounting profession with a mission to establishing and promoting adherence to high quality international standards. It collaborates with major public accounting firms, such as PricewaterhouseCoopers to carry out extensive studies to improve the ethicality of trainee accountants and believes that substantial emphasis should be given to ethics education at the university level, even if this is at the expense of technical training (IFAC Information Paper, 2006).

This study of Malaysian accounting students was motivated by the nation's drive to reform the management and performance of its business sector and one of the aims of its 2020 Vision (www.wawasan2020.com/vision/) is to improve its status as an ethical nation. The Ministry of Higher Education (MOHE) Malaysia has set general standards and issued Guidelines on Standard of Specific Disciplines at Bachelor Degree Level. The guidelines state that the general goal of 
accounting education is "to educate, build expertise and shape good character in line with the needs of the nation and the accountancy profession" (Ministry of Higher Education Malaysia, 2005). Importantly, the possession and practice of ethical values is placed first on its list of priorities.

For the past two decades, numerous studies have been conducted to determine the effectiveness of a single ethics course in developing ethical judgement making ability (for example, Abdolmohammadi and Reeves, 2000; Burks, 2006; Dellaportas, 2006; Jewe, 2008; LaGrone et al., 1996; Shawver, 2006; Weber, 1990). The mixed results of these studies suggest that the effectiveness of an ethics course remains debatable. Some researchers, who demonstrated positive short term benefits, were concerned about the continuance of these benefits once students entered the workplace with some post course studies showing that improvements are in fact short-lived (LaGrone et al., 1996; Weber, 1990).

Experience is fundamental to the training of an accountant. In most Malaysian universities, accounting students have the advantage of being involved in practical training (known locally as industrial training or internship). In these universities, training is part of the tertiary education curriculum where students are allocated to audit firms or accounting-related organizations. During training, that lasts as long as six months, students have the opportunity to interact and work with supervisors, colleagues, clients and the community. To the extent that social influence, personal interactions, work pressures and organizational cultures have the potential to influence moral cognition, this study explores the effect of an intervention (practical training) following the completion of a prior intervention (ethics course). It is anticipated that practical training can provide the students with a stimulating experience and one that may offer an 
“exposure to persons of mature moral thinking", thus affecting students' moral judgement making ability (Rest et al., 1999: 125).

This longitudinal study investigates the ethical development of Malaysian accounting students after completion of a moral education program (MEP) that includes an ethics course and subsequent practical training. Emphasis is placed on the examination of students' cognitive moral development (Kohlberg, 1976). The study involves three points of data collection, prior to an ethics course, after an ethics course, and after practical training.

This study is expansive in the sense that it provides longitudinal data involving multiple Malaysian universities. Other related studies, for example, La Grone et al. (1996), Dellaportas (2006), Abdolmohammadi and Reeves (2000), were conducted at one location. Although studies in ethical development among accounting students are voluminous, the literature involving Malaysian accounting students' moral development is limited, particularly employing Rest's (1986) Defining Issues Test (DIT) instrument. The studies that have involved Malaysian students are either focused on business students rather than accounting students (for example, Goodwin and Goodwin, 1999) or have focussed on moral awareness rather than judgement making ability (for example, O’ Leary and Mohamad, 2006). In addition, no attempt has been made to evaluate the moral efficacy of an MEP provided by Malaysian universities involving two forms of intervention, namely an ethics course followed by practical training.

This study is significant for two reasons. Firstly, the findings will be an indicator of the effectiveness of an MEP provided by Malaysian accounting faculties in relation to ethical development. In the context of this paper, an MEP refers to the inclusion of an ethics course and 
practical training. Several groups of accounting stakeholders benefit from this study, for example, academia, practitioners (who supervise students during practical training) and education regulators. For example, the results of this study may encourage educators to revisit ethics interventions and review content and delivery processes in order to better achieve the objectives

of the program. Secondly, the results will contribute to the limited literature in the area of ethics in a Malaysian setting.

This paper will report the effects of a specific MEP on ethical judgement making ability, outcomes that have prima facie relevance to future accountants in Malaysia and arguably elsewhere in the global community. Section 1 of the paper provides an overview of the study. Section 2 discusses the theoretical framework adopted in the study and reviews the key literature. Section 3 presents the research methodology followed by the presentation of results in Section 4. The final section discusses the implications and limitations of the study.

\section{Theoretical Framework and Literature Review}

\section{Theory of Moral Reasoning and Development}

The study is heavily influenced by the works of Kohlberg $(1976 ; 1981 ; 1984)$ and Rest (1986), who have contributed significantly to the field of cognitive moral development from a behavioural perspective. Kohlberg's theory is based on the belief that individuals go through a cognitive process in judgement making ability based on the levels of moral development the individual has attained. The theory presents three levels of moral development, with each level subdivided into two stages as summarised in Table 1. 
Table 1: Kohlberg's stages of moral development

\begin{tabular}{lcl}
\hline Level & Stage & Description \\
\hline $\begin{array}{l}\text { Pre- } \\
\text { Conventional }\end{array}$ & 2 & $\begin{array}{l}\text { Individual obeys the rules to avoid punishment. } \\
\text { Individual behaves morally to gain personal rewards from others or } \\
\text { makes choices amongst alternatives that will benefit the individual. }\end{array}$ \\
\hline Conventional & 3 & $\begin{array}{l}\text { Individual is concerned with maintaining good interpersonal } \\
\text { relationships. } \\
\text { From these relationships come a sense of fairness, mutual loyalty and } \\
\text { dedication where the individual develops an ability to adhere to legal and } \\
\text { moral codes. }\end{array}$ \\
\hline $\begin{array}{l}\text { Post- } \\
\text { Conventional }\end{array}$ & 5 & $\begin{array}{l}\text { The correct behaviour is a combination of individuals' rights and } \\
\text { principles agreed upon by society. } \\
\text { The right behaviour means acting according to an individual's own } \\
\text { ethical principles, in other words, unwritten global deontological ethical } \\
\text { principles of justice, duties and equal human rights are followed at this } \\
\text { stage }\end{array}$ \\
\hline
\end{tabular}

Source: (Kohlberg, 1984; Venezia, 2004).

Kohlberg also believed that life experience and various factors surrounding individuals can influence levels of ethical development, particularly the progress to the Post-Conventional level (Kohlberg, 1984; LaGrone et al., 1996).

Rest (1986) expanded Kohlberg's work by proposing a comprehensive four-component model for moral behaviour, which he described as the combination of four inner processes;

1. Moral sensitivity: identifying the morality of a situation or event, role taking; interpreting the intensity of issues, and being aware that there is a moral problem when it exists.

2. Moral judgement making ability: deciding which action would be most justifiable in a given situation.

3. Moral motivation: the degree of commitment or motivation to taking a moral course of action, valuing moral values over other values, and taking personal responsibility for moral outcomes.

4. Moral character: ego strength, persisting in a moral task, having courage, overcoming fatigue and temptations, and implementing subroutines that serve a moral goal. 
Rest's (1986) contribution to the theory of moral development involves the construction of an instrument (DIT), which determines a person's judgement making ability in accordance with Kohlberg's stages of moral development (Table 1). However, Rest's model of moral judgement making ability differs from Kohlberg's Moral Judgment Interview (1981). Elm and Weber (1994) argue that Rest's model of moral judgement making ability using DIT assesses "an individual's tendency to use concepts of justice based on cooperation in his or her moral thinking, while Kohlberg's model assesses an individual's use of justice concepts, focusing more on exchange and individual interest" (p.346). Similar to Kohlberg, Rest et al. (1999) raise the issue of life experiences and real-life morality. They assert that "development is more a matter of richness of experience and stimulating experiences than the mere passage of years" (p.125). Both Kohlberg and Rest emphasize the role of education and social cooperation in assisting individuals' progress from one moral cognitive stage to another. Thus, the DIT is used in this study to assess changes in ethical judgement making ability within a period of accounting education consisting of ethics course and practical training interventions.

\section{Ethics Research in Accounting}

Many studies that have investigated the level of ethical judgement making ability of students are cross-sectional (for example, Ahadiat and Mackie, 1993; Aileen and Violet, 2000; Bonawitz, 2002; Chan and Leung, 2006; Coate and Frey, 2000; Cohen et al., 1998; Cowton and Cummins, 2003; David and Jill, 2003; David, 2004; Delaney, 2005; Dellaportas, 2004; Earley and Kelly, 2004; Eynon et al., 1996; Gautschi and Jones, 1998; Lowry, 2003; Shaub, 1994). These papers report the effectiveness of ethics intervention programs by comparing students or graduates with and without an ethics education. Gautschi and Jones (1998), for example, used a control group 
of marketing students that were not exposed to ethical issues and a treatment group which attended a business ethics course, and deduced that the business ethics course was able to enhance student ability to recognize ethical issues in a business setting. Similarly, using the DIT, a study by Bonawitz (2002) found that students with ethics training scored higher than those without training. Likewise, auditors and auditing students who undertook ethics courses during college also reflected a higher level of moral reasoning ability (Eynon et al., 1996; Shaub, 1994). In the Malaysian setting, Mohamad and O'Leary (2008) conducted a pre and post study on final year accounting students attending a business ethics course to determine its effectiveness. Using five ethical accounting-related vignettes, they tested students prior to the course commencing and again six weeks into the course and found that ethical attitudes had improved.

Various extraneous issues impact the validity of cross-sectional studies and for this reason many researchers have conducted pre and post tests on the effects of ethics education on ethical development. However, results from these longitudinal studies have been mixed. Despite efforts at integrating ethics into the curriculum with a standalone ethics course, studies have shown that some courses do not have an impact on ethical reasoning and are not significant in influencing ethical development (Borkowski and Ugras, 1992; Burks, 2006; Earley and Kelly, 2004; Ponemon, 1993; St. Pierre et al., 1990; Venezia, 2004). There is however little in these studies to suggest why this may be the case.

In contrast, other studies such as LaGrone et al. (1996), Armstrong (1993), Abdolmohammadi and Reeves (2000), have identified positive benefits by accounting students with respect to the effectiveness of an ethics course. Dellaportas (2006) and Shawver (2006) asked participants to complete the DIT at the beginning and end of the ethics course and found that the intervention 
improved the level of ethical judgement making ability by the increase of means of p-scores (index designed to measure the extent to which an individual applies Post-Conventional reasoning) and thus proposed that a dedicated course in ethics education is effective in improving reasoning ability. A more recent study by O'Leary (2009) supports this outcome with evidence demonstrating a positive effect of an ethics course on accounting students

Studies that examine the impact of practical training on ethical development are scarce. However, results have generally found that practical training offers benefits for generic skills such as leadership, communication and interpersonal relations as these improve marketability upon graduating and are highly sought by employers (Jackling and De Lange, 2009; Teed and Bhattacharya, 2002). Students were found to be more mature after being exposed to real tasks and involvement with different levels of employees (Cook et al., 2004). Cross-sectional studies have examined students who had been exposed to a working environment and those without exposure. These studies report that students in the former group have higher ethical standards compared to students who had no exposure (Keller et al., 2007; Porco, 2003; Shaub, 1994). Porco (2003) reported that the longer duration of training has a significant impact on students' moral development (higher level of ethical judgement), while Keller et al. (2007) suggested that real world experiences provide an ability to develop a better appreciation of the needs of others. Similarly, a study by Dellaportas et al. (2006) suggested that a year of industrial placement improved students' ethical judgement making ability. Everyday socialization and interaction processes make the workplace experience an informal way of inculcating moral values. Clikeman and Henning (2000) investigated the effect of socialization during a university accounting program. This study found that the socialization process during the three year program made students more aware of the deleterious effects of misreporting and earnings 
management. This is consistent with Kohlberg's (1984) assertion that the role of social interaction is very important to moral development but as a stimulus rather than direct influence.

LaGrone et al. (1996) and Abdolmohammadi and Reeves (2000) extended their pre and post ethics course studies by conducting follow-up tests. LaGrone et al. (1996) found that the pscores of their experimental group declined after six months, and argued that the effects of an ethics intervention may be transitory. A longitudinal survey by Abdolmohammadi and Reeves (2000) involved a slightly different approach. This study of American students tested the effect of a four year education program, and included a pre and post test of DIT to evaluate the effectiveness of an ethics course. Their study demonstrated that in addition to the four year program, an ethics course had a more significant positive impact on students' moral reasoning ability. Welton and Guffey (2009) conducted a three stage study to determine whether the effect of an ethics education on moral reasoning is transitory or permanent. The results showed significant gains in moral reasoning. A follow-up test was conducted three years after the completion of an accounting program and found that improvements in moral reasoning ability were sustained and do not diminish when students enter the accounting profession (Welton and Guffey, 2009).

\section{Methodology}

Data were collected at three points of time over a one year period. Time 1 corresponds with the start of the semester; Time 2, the end of the semester; and Time 3, six months later. The Experiment group consisted of students from two public and two private universities who experienced both interventions, an ethics course followed by a six months period of practical training. This group of students answered the research instrument prior to attending an ethics 
course (Time 1), after completing the course (Time 2), and after completing the practical training (Time 3). Students in the Control group were from two public universities who did not enrol in an ethics course and did not undertake practical training. These students answered the research instrument at approximately the same time throughout the year as the Experiment group.

The 14 week ethics course is a dedicated course and the course syllabi from all universities were collected with examination revealing that there were no major differences. For example, all syllabi include course objectives that aim to make students understand the ethical philosophy and improve ethical awareness and reasoning among students. Hence in all universities the course covered elements of ethical theories and issues although in varying proportions.

It is important to note that students in this study were in their final year of accounting with similar levels of exposure to accounting knowledge and a similar duration of social interaction.

In assessing ethical judgement making ability, the short form of DIT (Rest, 1990) was used, consisting of three scenarios (refer Appendix 1) highlighting some sort of ethical dilemma. Each case was followed by 12 statements or items representing various stages of moral reasoning. Students were asked to rate each statement based on its importance in deriving an action for each dilemma using a five point scale (Great, Much, Some, Little and No Importance). Also included are M type statements, which Rest (1990) refers to as a reliability check. In other words they are statements which are meaningless or nonconventional. M type statements are included to identify respondents who answer without reading or do not give serious consideration to the statements and may result in respondents being removed from the sample. After rating each item in the cases, students then rank the four most important statements. The rankings should be 
consistent with the ratings selected earlier with this comparison referred to as a 'consistency check' (Rest, 1990).

The p-score is calculated manually, strictly adhering to the protocols in the DIT Manual. The pscore, with a possible range of 0 to 95 , reflects "the relative importance participants give to principled moral considerations represented by Stages 5 and 6 in making moral decisions" (Rest et al., 1997: 498). Principled reasoning (as measured by the p-score) involves the articulation of higher level cognitive ability when making a judgment based on either an individuals' rights and generally agreed societal principles, or on an individuals' ethical principles founded on justice and equal human rights. Minor modifications are made to the three cases to suit the Malaysian context, for example the names of the characters have been changed to make them sound local (Zahir for Heinz, Puan Salmah for Mrs. Jones, Karim for Mr. Thompson and Lim for Fred).

In addition to the DIT, the questionnaire for Time 3 incorporated additional questions relating to practical training. Students were required to state the proportion of work undertaken based on assigned tasks (for example, auditing, administration), their perceptions on the benefits of training, and their exposure to ethical situations during practical training. This section included specific questions on ethical dilemmas faced during their training and open ended questions allowing students to detail any ethical dilemmas they encountered and how those issues were addressed.

In this study, the General Linear Model for Repeated Measures is used as a means of testing whether changes of conditions affecting a group of subjects influences their behavioural responses. The process involves a transformation of three variables (for example using 
difference contrasts) and subjecting them to a repeated measures ANOVA, which tests the hypothesis that "the overall mean latency effect is 0" (Norusis, 1994). Each subject is used as his or her own control and so individual differences can be partialed out of the error term (Field, 2005). The objective is to establish whether a systematic influence (in this instance, the presence of an MEP consisting of an ethics course followed by practical training) can explain changes in ethical judgement making ability. A repeated measures design allows for the use of a smaller number of respondents including students in the Experiment and Control groups who participated in all three points of data collection and were analysed using this method. With this process in mind the following hypotheses will be tested:

$\mathrm{H}_{1}$ : The ethical judgement making ability of Malaysian accounting students will improve after completing an MEP that includes an ethics course and practical training (Experiment group).

$\mathrm{H}_{2}$ : The ethical judgement making ability of Malaysian accounting students who completed their studies without undertaking a course in ethics and practical training will not alter significantly. (Control group)

\section{Results}

After conducting the reliability and consistency checks recommended by Rest (1990) for the three-story DIT, a total of 175 respondents were eliminated in Time 1. By exercising the same protocols, a further 39 respondents were eliminated in Time 2 while 13 respondents were excluded in Time 3 leaving 113 students who had completed all three research instruments.

Using the p-scores of the three points of time, Panel 1 of Table 2 reports the descriptive (means of p-scores for every point of time) and the required Mauchly's Test of Sphericity (Sig $=0.859$ for Experiment and 0.172 for Control). The latter tests the assumption that the relationship between 
pairs included in the experimental condition are similar, which are not violated (Field, 2005).

Panel 1 also highlights that the Control group average p-score is lower (24.2) compared to the Experiment group (28.3) before any intervention takes place.

Table 2: Repeated measures results

\begin{tabular}{|c|c|c|c|c|c|c|}
\hline & \multicolumn{3}{|c|}{ EXPERIMENT } & \multicolumn{3}{|c|}{ CONTROL } \\
\hline Panel 1: Mauchly's & \multicolumn{3}{|c|}{ Mean p-score } & \multicolumn{3}{|c|}{ Mean p-score } \\
\hline Time 1 & \multicolumn{3}{|c|}{28.33} & \multicolumn{3}{|c|}{24.22} \\
\hline Time 2 & \multicolumn{3}{|c|}{27.48} & \multicolumn{3}{|c|}{26.66} \\
\hline Time 3 & \multicolumn{3}{|c|}{32.52} & \multicolumn{3}{|c|}{26.22} \\
\hline Mauchly’s W & \multicolumn{3}{|c|}{0.997} & \multicolumn{3}{|c|}{0.763} \\
\hline Significance & \multicolumn{3}{|c|}{0.859} & \multicolumn{3}{|c|}{0.172} \\
\hline $\begin{array}{l}\text { Panel 2: Test of } \\
\text { within-Subjects } \\
\text { Effects }\end{array}$ & $\begin{array}{c}\text { Type III Sum } \\
\text { of Squares }\end{array}$ & $F$ & Sig & $\begin{array}{c}\text { Type III Sum } \\
\text { of Squares }\end{array}$ & $F$ & Sig \\
\hline Sphericity Assumed & 1423.292 & 4.583 & $0.011 *$ & 50.911 & 0.143 & 0.867 \\
\hline Greenhouse-Geisser & 1423.292 & 4.583 & $0.011^{*}$ & 50.911 & 0.143 & 0.824 \\
\hline Huynh-Feldt & 1423.292 & 4,583 & $0.011 *$ & 50.911 & 0.143 & 0.846 \\
\hline Lower-bound & 1423.292 & 4.583 & $0.011^{*}$ & 50.911 & 0.143 & 0.711 \\
\hline $\begin{array}{l}\text { Panel 3: Test of } \\
\text { within-Subjects } \\
\text { Contrasts }\end{array}$ & $\begin{array}{c}\text { Type III Sum } \\
\text { of Squares }\end{array}$ & $F$ & Sig. & $\begin{array}{c}\text { Type III Sum } \\
\text { of Squares }\end{array}$ & $F$ & Sig. \\
\hline Time 1 vs. Time 2 & 70.873 & 0.226 & 0.636 & 89.695 & 0.205 & 0.658 \\
\hline Time 2 vs. Time 3 & 2483.615 & 8.442 & $0.005 * *$ & 2.957 & 0.007 & 0.936 \\
\hline Time 1 vs. Time 3 & 1715.390 & 5.294 & $.024 *$ & 60.080 & 0.330 & 0.575 \\
\hline
\end{tabular}

** Significant at the 0.01 level (2-tailed); * Significant at the 0.05 level (2-tailed).

Panel 2 identifies the effect of the MEP by reporting the 'test of within-subject effects' which illustrates the degree to which total variability (in judgement making ability) is explained by the experimental effect (exposure of students to the MEP). Four methods for calculating the within- 
subjects effects are included in Panel 2 and all produce significant values of F. Panel 2 highlights that the experimental effect is significant as identified by the $\mathrm{F}$ ratio of the systematic variance (experimental effect) to the unsystematic variance (due to extraneous factors), suggesting that the program provides a significant contribution to the explanation of the improvement in moral judgement making ability over time for the Experiment group. For the control group, Panel 2 also identifies the effect of the absence of an MEP and illustrates that the total variability, (in judgement making ability), cannot be explained by this alternative education program. Abdolmohammadi and Reeves (2000) have suggested that the effect size of an intervention can be determined by dividing the average mean difference of the pre and post $p$-score by the standard deviation of the pre test p-score. The effect size of 0.00 to 0.33 is considered low, moderate at 0.34 to 0.66 and a high effect when the size is 0.67 to 1.00 . Results show that although attending an ethics course and practical training has developed students' judgement making ability, the effect size is low (0.142 and 0.317 respectively).

Panel 3 of Table 2 outlines the 'test of within-subject contrasts', which illustrates the singular effect of each component of the MEP. The results show that an ethics course intervention (Time 1 vs. Time 2) contributed little to observed changes in principled reasoning ability while the practical training intervention provided a significant contribution (Time 2 vs. Time 3). The MEP as a whole (including both ethics course and practical training) contributes to and explains the significant improvement in students' ethical judgement making ability and results in hypothesis $\mathrm{H}_{1}$ being accepted. For the Control group (exposed to no MEP), Panel 3 of Table 2 reports no significant improvement in ethical judgment making ability. Hence, hypothesis $\mathrm{H}_{2}$ may be accepted. 
The development of p-scores between the Experiment group and Control group of students are further illustrated in Figure 1 and Figure 2.

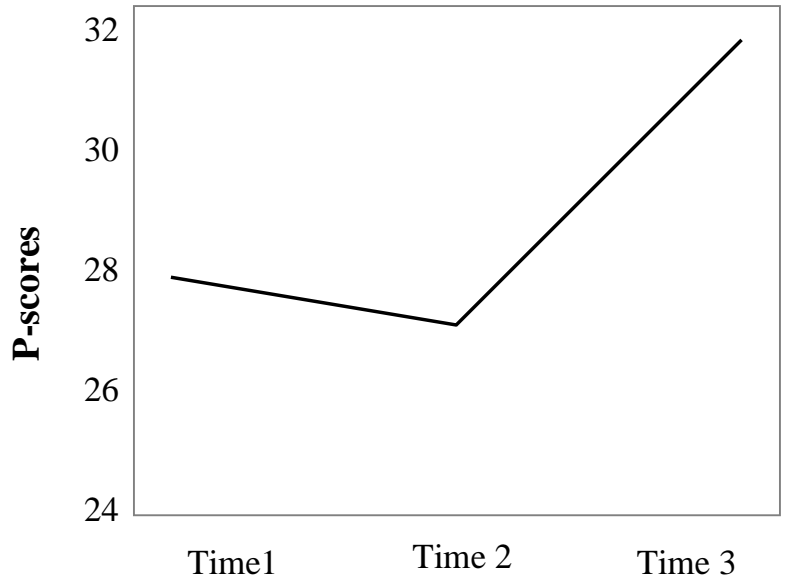

Figure 1: Changes in p-cores (Experiment)

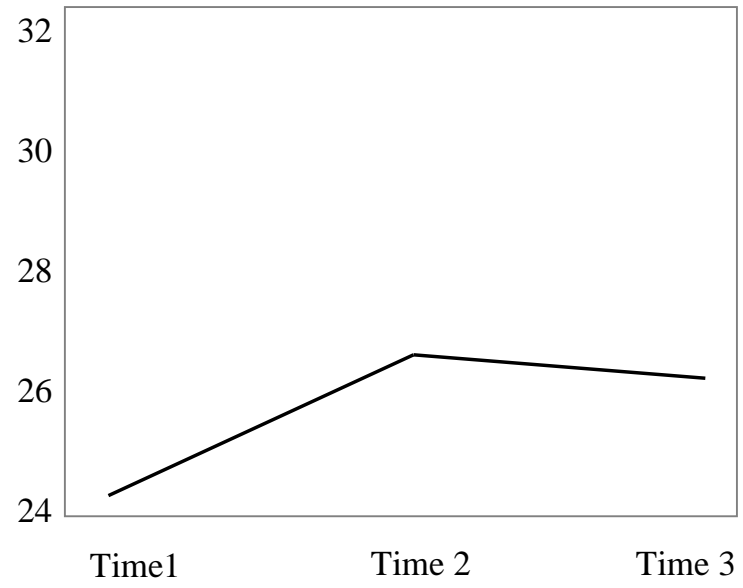

Figure 2: Changes in p-scores (Control)

The results in Table 2 (for the Experiment group) and Figure 1 highlight that practical training provides a significant contribution to the development of ethical judgement making ability within the MEP. There are several factors that appear to influence the positive benefits of training. During the practical training, employers assigned different tasks to the Malaysian students, for example, auditing, taxation and book keeping. Each student provided information about the proportion of time spent on the tasks. Students who reported spending more than $70 \%$ of their time on a particular task are categorized as "focused" while those who were involved in a number of tasks are grouped as "non-focused". A paired sample t-test was used to compare the changes in p-scores in the post ethics course and post practical training between the focused and nonfocused groups. Among the 98 students who participated in both interventions, 56 students experienced a 'focused' task program during practical training while 42 were 'non-focused'. The 
tests involved the determination of p-scores with the results provided in Table 3 for both groups of students highlighting that the average levels of ethical judgement making ability increased significantly for the non-focused group.

Table 3: Effects of practical training on p-scores between task groups

\begin{tabular}{|c|c|c|c|c|c|c|}
\hline FOCUSED & $\begin{array}{c}\text { Mean } \\
\text { P score }\end{array}$ & Std. Dev. & $\begin{array}{l}\text { Mean } \\
\text { diff. }\end{array}$ & $\begin{array}{l}\text { Std. } \\
\text { Dev. }\end{array}$ & $\mathrm{t}$ & Sig. \\
\hline Time 2 & 29.02 & 13.73 & \multirow{2}{*}{-2.48} & \multirow{2}{*}{16.49} & \multirow{2}{*}{-1.076} & \multirow{2}{*}{.287} \\
\hline Time 3 & 31.50 & 14.75 & & & & \\
\hline NON-FOCUSED & $\begin{array}{c}\text { Mean } \\
\text { P score }\end{array}$ & Std. Dev. & $\begin{array}{l}\text { Mean } \\
\text { diff. }\end{array}$ & $\begin{array}{l}\text { Std. } \\
\text { Dev. }\end{array}$ & $\mathrm{t}$ & Sig. \\
\hline Time 2 & 25.62 & 14.55 & \multirow{2}{*}{-7.79} & \multirow{2}{*}{17.44} & \multirow{2}{*}{-2.942} & \multirow{2}{*}{$.005 * *$} \\
\hline Time 3 & 33.41 & 14.88 & & & & \\
\hline
\end{tabular}

** Significant at the 0.01 level (2-tailed);

The changes of p-scores between students who completed focused and non-focused tasks are further illustrated in Figure 3.

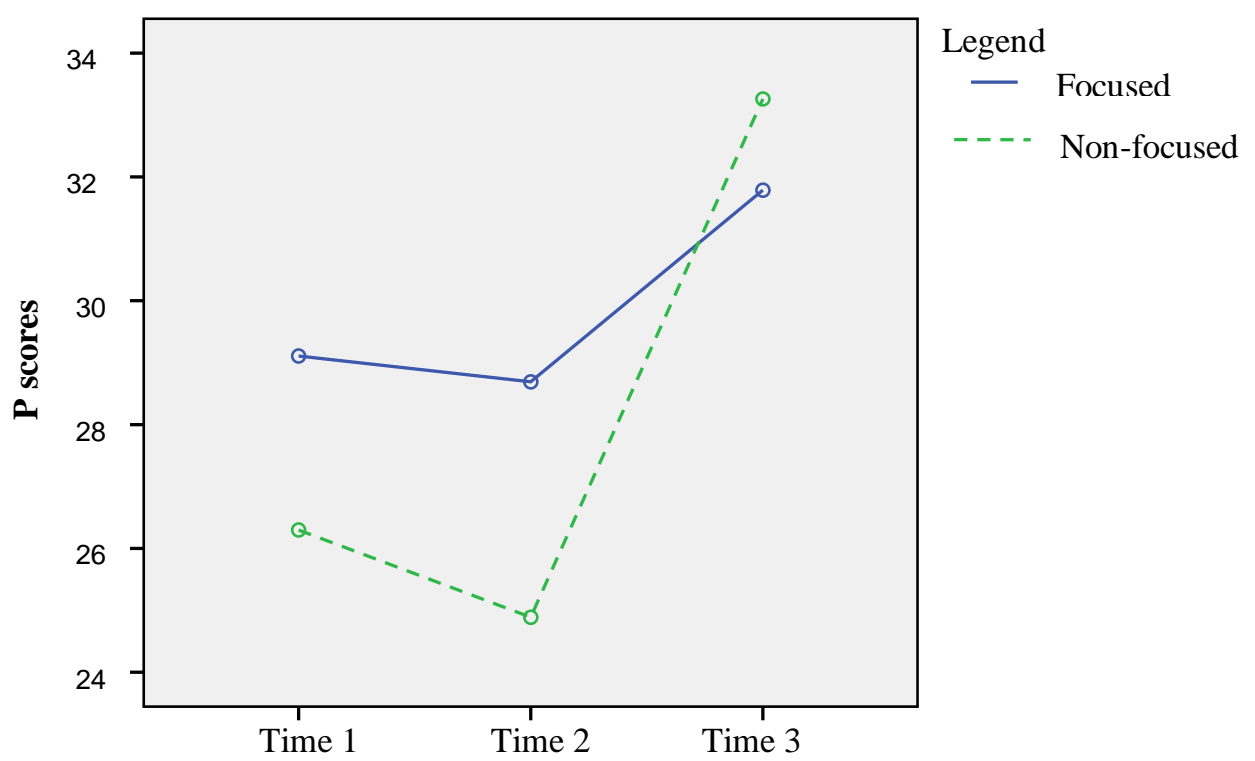




\section{Figure 3: Graphs of changes in levels of ethical judgement making ability between focused and non-focused task groups}

\section{Discussion and Conclusion}

This study reports changes in ethical judgement making ability among Malaysian accounting students over a twelve month period during which they were subjected to two forms of intervention, a dedicated ethics course of study followed by a period of practical training. Ethical judgement making ability is measured using a widely recognised three-story version of the Defining Issues Test (DIT) developed by Rest (1986). Subsequent analysis involving GLM Repeated Measures indicated that an MEP consisting of both an ethics course and practical training explains improvements in ethical judgement making ability. In contrast, an alternative program involving no equivalent MEP showed no significant association with judgement making ability.

In terms of the ethics course, results show that there are no significant changes in ethical judgement making ability of students in the Experimental group, which is consistent with past studies (Borkowski and Ugras, 1992; Jewe, 2008; Ponemon, 1993; Venezia, 2004). Nevertheless, what is demonstrated and emphasized in this paper is that an MEP consisting of an ethics course and practical training together explain improvements in cognitive moral development (i.e., principled reasoning ability as measured by the p-score). This study also establishes that the practical training component contributed significantly to the improvement in principled reasoning ability which is in line with findings by Dellaportas et al. (2006), implying that a socialization process and the interaction with the environment are significant issues influencing moral reasoning. These findings align with Kohlberg's (1984) and Rest's (1986) 
theories of the influence of these factors on moral development. The results reflect Rest's assertion that individuals' ethical judgement making ability improves when there is some sort of "richness" in experience (Rest et al., 1999). It is further noted that the type and extent of tasks performed during training make a differential impact on p-scores. Students who undertook various jobs (non-focused tasks) improved their p-scores significantly compared to those who focussed only on a certain type of task. This appears to be due to the wider circle of socialization with students in the non-focused group arguably faced with more complex interactions and exposure to a potentially wider range of ethical situations. In other words, students involved in multiple tasks over time tend to deal with a range of socialisation issues of networks and group interactions, including different supervisors, colleagues and clients.

Based on the results, this paper proposes a number of practical implications. At the tertiary level, the findings are an indicator of the effects of MEPs provided by Malaysian accounting faculties. The results indicate that the social interaction during practical training makes a significant impact with students undertaking multiple tasks improving significantly in their reasoning ability compared to their task focussed counterparts. Therefore, it is suggested that practical training should be conducted in an unfocused manner where students should be exposed to a variety of potentially ethical situations.

The Control group (no interventions) showed no significant improvement in their reasoning ability during the period tested. Therefore, universities that have not introduced any form of intervention should consider the inclusion of an ethics course and particularly practical training in their accounting curricula. 
In addition to a code of conduct, it is further recommended that accounting graduate trainees should be given the opportunity to rotate their jobs and be given greater exposure to a variety of tasks as this will lead to a broader circle of socialization which would assist in developing a range of skills to improve their ethical judgement making ability.

The findings of this study contribute to the body of knowledge in a number of ways. Firstly, this study has significantly contributed to the literature on the effects of moral education programs consisting of ethics education and practical training, and provides longitudinal data from a number of accounting programs held at Malaysian universities. Further, the study has added to the literature on students' practical training experience and its effect on moral judgement making ability. Most studies relating to practical training investigate the development of technical and soft skills, but not ethical development. Although the 'non-focused' type of job task was found to influence the level of improvement in ethical cognition, this is self-reported information from the students in this study. The results therefore should be treated with some caution but it is noteworthy for consideration of future research.

It is important to stress that the significant improvements in moral reasoning ability identified in this study applied to a fairly random group of accounting students (98 from four Malaysian universities) who were subject to an MEP that included an ethics course and subsequent practical training. The sample selection process (including rigorous validation) and the subsequent attrition of student numbers prior to the completion of Time 2 and 3 of the longitudinal study meant that it was not possible to test whether the significant improvements reported after completion of training were contingent on students completing an ethics course. The multivariate test (GLM Repeated Measures) established the efficacy of the MEP as described but it was not possible to 
establish whether improvements in reasoning ability would have occurred if the study had included a sizable group of students who completed training without previously undertaking an ethics course. A broader sample of students would be necessary to confirm whether for instance significant improvements in moral judgment making ability following training might depend simply on exposure to the moral content covered in other tertiary units in accounting. This issue deserves to be investigated further.

The low numbers in the Control group is also acknowledged. This limitation is due to attrition and to the increasing number of Malaysian universities offering an ethics course and practical training. Past studies have highly recommended that a control group would validate claims of the effects of an intervention program and it is recommended that future research attempt to capture higher student numbers that have not taken part in such a program.

Future research may examine the demographics (for example, gender, ethnicity, academic performance, differences in teaching and learning processes) and organizational factors (for example, firm size or type of firm students undertake training), and determine which group benefits most from the MEP in relation to ethical development.

\section{References:}

"The way forward - Vision 2020." www.wawasan2020.com/vision/

Abdolmohammadi, M. J. and M. F. Reeves. 2000, "Effects of education and intervention on business students' ethical cognition: A cross sectional and longitudinal study", Teaching Business Ethics Vol. 4 No. 3, pp.269-284. 
Ahadiat, N. and J. J. Mackie. 1993, "Ethics education in accounting: An investigation of the importance of ethics as a factor in the recruiting decisions of public accounting firms", Journal of Accounting Education Vol. 11 No. 2, pp.243-257.

Aileen, S. and R. Violet. 2000, "Ethics-related responses to specific situation vignettes: Evidence of gender-based differences and occupational socialization", Journal of Business Ethics Vol. 28 No. 1, pp.73-85.

Armstrong, M. B. 1993, "Ethics and professionalism in accounting education: A sample course", Journal of Accounting Education Vol. 11 No. 1, pp.77-92.

Bonawitz, M. F., 2002. Analysis and comparison of the moral development of students required to graduate with an ethics course. DBA. Miami, Florida, USA: Florida International University.

Borkowski, S. C. and Y. J. Ugras. 1992, "The ethical attitudes of students as a function of age, sex and experience", Journal of Business Ethics Vol. 11 No. 12, pp.961-979.

Burks, B. D., 2006. The impact of ethics education and religiosity on the cognitive moral development of senior accounting and business students in higher education. DBA. Fort Lauderdale-Davie, Florida, USA: Nova Southeastern University.

Chan, S. Y. S. and P. Leung. 2006, "The effects of accounting students' ethical reasoning and personal factors on their ethical sensitivity", Managerial Auditing Journal Vol. 21 No. 4, pp.436457.

Clikeman, P. M. and S. L. Henning. 2000, "The socialization of undergraduate accounting students", Issues in Accounting Education Vol. 15 No. 1, pp.1-11.

Coate, C. J. and K. J. Frey. 2000, "Some evidence on the ethical disposition of accounting students: Context and gender implications", Teaching Business Ethics Vol. 4 No. 4, pp.379-404.

Cohen, J. R., L. W. Pant and D. J. Sharp. 1998, "The effect of gender and academic discipline diversity on the ethical evaluations, ethical intentions and ethical orientation of potential public accounting recruits", Accounting Horizons Vol. 12 No. 3, pp.250-270.

Cook, S. J., R. S. Parker and C. E. Pettijohn. 2004, "The perceptions of interns: A longitudinal case study", Journal of Education for Business Vol. 79 No. 3, pp.179-185.

Cowton, C. J. and J. Cummins. 2003, "Teaching business ethics in UK higher education: Progress and prospects", Teaching Business Ethics Vol. 7 No. 1, pp.37-54.

David, F. B. and M. D. A. Jill. 2003, "Accounting students as surrogates for accounting professionals when studying ethical dilemmas: A cautionary note", Teaching Business Ethics Vol. 7 No. 3, pp.187-204.

David, M. 2004, "After Andersen: An experience of integrating ethics into undergraduate accountancy education", Journal of Business Ethics Vol. 54 No. 4, pp.385-398. 
Delaney, J. S., 2005. The impact of ethics education on the moral reasoning ability of accounting students. DBA dissertation. Davenport, Iowa, USA: St. Ambrose University.

Dellaportas, S. 2004, "The moral reasoning abilities of Australian and Malaysian accounting students: A comparative analysis", Asian Review of Accounting Vol. 12 No. 1, pp.48-63.

Dellaportas, S. 2006, "Making a difference with a discrete course on accounting ethics", Journal of Business Ethics Vol. 65 No. 4, pp.391-404.

Dellaportas, S., B. Cooper and P. Leung. 2006, "Measuring moral judgement and the implications of cooperative education and rule-based learning", Accounting and Finance Vol. 46 No. 1, pp.5370 .

Earley, C. E. and P. T. Kelly. 2004, "A note on ethics educational interventions in an undergraduate auditing course: Is there an "Enron effect"?", Issues in Accounting Education Vol. 19 No. 1, pp.53-71.

Elm, D. R. and J. Weber. 1994, "Measuring moral judgment: The moral judgment interview or Defining Issues Test?", Journal of Business Ethics Vol. 13 No. 5, pp.341-355.

Eynon, G., N. T. Hill, K. T. Stevens and P. Clarke. 1996, "An international comparison of ethical reasoning abilities: Accounting students from Ireland and the United States", Journal of Accounting Education Vol. 14 No. 4, pp.477-492.

Field, A. 2005. Discovering statistics using SPSS, Sage Publications, London, UK.

Gautschi, F. H., III and T. M. Jones. 1998, "Enhancing the ability of business students to recognize ethical issues: An empirical assessment of the effectiveness of a course in business ethics", Journal of Business Ethics Vol. 17 No. 2, pp.205-216.

Goodwin, J. and D. Goodwin. 1999, "Ethical judgments across cultures: A comparison between business students from Malaysia and New Zealand", Journal of Business Ethics Vol 18, pp.267281.

Harding, F. 1999. "Corruption: Rising to the challenge." In IFAC: Articles Library.

IFAC Information Paper. 2006. "Approaches to the development and maintenance of professional values, ethics and attitudes in accounting education programs." ed. IFAC Education Committee. New York: International Accounting Education Standards Board (IAESB). International Federation of Accountants.

Jackling, B. and P. De Lange. 2009, "Do accounting graduates' skills meet the expectations of employers? A matter of convergence or divergence", Accounting Education: An International Journal Vol. 18 No. 4\&5, pp.369-385.

Jewe, R. 2008, "Do business ethics courses work? The effectiveness of business ethics education: An empirical study", Journal of Global Business Issues-Conference Edition 2008 Vol. No., pp.15 . 
Keller, A. C., K. T. Smith and L. M. Smith. 2007, "Do gender, educational level, religiosity and work experience affect the ethical decision-making of U.S. Accountants?", Critical Perspectives on Accounting Vol. 18 No. 3, pp.299-314.

Kohlberg, L. 1976. Moral stages and moralization: The cognitive-developmental approach. In Moral development and behavior: Theory, research, and social issues, ed. T. Lickona. New York: Holt Rinehart \& Winston.

Kohlberg, L. 1981. Essays on moral development. The philosophy of moral development. Moral stages and the idea of justice, Harper \& Row, New York, New York, USA.

Kohlberg, L. 1984. The psychology of moral development: The nature and validity of moral stages, Harper \& Row, San Francisco.

LaGrone, R. M., R. E. Welton and J. R. Davis. 1996, "Are the effects of accounting ethics interventions transitory or persistent?", Journal of Accounting Education Vol. 14 No. 3, pp.259276.

Lowry, D. 2003, "An investigation of student moral awareness and associated factors in two cohorts of an undergraduate business degree in a British university: Implications for business ethics curriculum design", Journal of Business Ethics Vol. 48 No. 1, pp.7-19.

Ministry of Higher Education Malaysia. 2005. "Guidelines on criteria and standards for educational programmes in the field of accountancy ", ed. Quality Assurance Division: Ministry of Higher Education Malaysia.

Mohamad, S., and C. O'Leary. 2008. The Successful Influence of Teaching Ethics on Malaysian Accountancy Students. Malaysian Accounting Review 7 (2): 1-15.

Norusis, J. M. 1994. SPSS professional statistics 6.1 SPSS Inc., Chicago, Ilinois.

O'Leary, C. 2009, "An empirical analysis of the positive impact of ethics teaching on accounting students ", Accounting Education: An International Journal Vol. 18 No. 4\&5, pp.505-520.

O'Leary, C., and S. Mohamad. 2006. A Tri-national Study of Accountancy Students' Ethical Attitudes. Malaysian Accountancy Review 5 (May 2006): 139-157.

Ponemon, L. A. 1993, "Can ethics be taught in accounting?", Journal of Accounting Education Vol. 11 No. 2, pp.185-209.

Porco, B. M., 2003. Factors affecting the cognitive moral development of undergraduate accounting students: Ethics education, internships, volunteerism and beta alpha psi. $\mathrm{PhD}$ dissertation. New York, New York, USA: Fordham University.

Rest, J. 1986. Moral development: Advances in research and theory, Praeger, New York, New York, USA.

Rest, J. 1990. DIT manual, University of Minneapolis Press, Minneapolis, Minnesota, USA. 
Rest, J., D. Narvaez, M. J. Bebeau and S. J. Thoma. 1999. Postconventional moral thinking a Neo-Kohlbergian approach, Lawrence Erlbaum Associates, Inc., Mahwah, New Jersey, USA.

Rest, J., S. J. Thoma, D. Narvaez and M. J. Bebeau. 1997, "Alchemy and beyond: Indexing the Defining Issues Test", Journal of Educational Psychology Vol. 89 No. 3, pp.498-507.

Shaub, M. K. 1994, "An analysis of the association of traditional demographic variables with the moral reasoning of auditing students and auditors", Journal of Accounting Education Vol. 12 No. 1, pp.1-26.

Shawver, T. J. 2006, "An exploration study assessing the effectiveness of a professional responsibility course", Global Perspectives on Accounting Education Vol. 3 No. 2006, pp.49-66.

St. Pierre, K. E., E. S. Nelson and A. L. Gabbin. 1990, "A study of the ethical development of accounting majors in relation to other business and non-business disciplines", The Accounting Educators Journal Vol. 3 No., pp.23-35.

Teed, D. G. and T. K. Bhattacharya. 2002, "Benefits of an accounting and finance internship program to students, business organizations and universities", Journal of Accounting and Finance Research Vol. 10 No. 2, pp.95-102.

Venezia, C. C., 2004. The ethical reasoning abilities of accounting students: Comparison between the U.S. And Taiwan. DBA dissertation. Nova Southeastern University.

Weber, J. 1990, "Measuring the impact of teaching ethics to future managers", Journal of Business Ethics Vol. 9 No. 3, pp.183-190.

Welton, R. E. and D. M. Guffey. 2009, "Transitory or persistent? The effects of classroom ethics interventions: A longitudinal study", Accounting Education: An International Journal Vol. 18 No. 3, pp.273-289.

\section{Appendix 1: DIT Scenarios}

\section{CASE 1}

A woman was near death from a rare type of cancer. There was one medicine that doctors thought might save her. It was a form of radium that the medical researcher in the same town had recently discovered. The medicine was expensive to make, but the medical researcher was charging ten times what the medicine actually cost to make. He spent RM200 for the medicine formula and charged RM2,000 for a small dose of the medicine. The woman needed at least 60 doses to cure; thus needed to raise RM120,000 for the medicine. The sick women's husband, Zahir, went to everyone he knew to borrow the money, but he could only raise about RM50,000, which is less than half of what they needed. He told the medical researcher that his wife was dying, and asked him to sell it cheaper or let him pay later. But the medical researcher said, "No, I discovered the medicine and I'm going to make money from it". So Zahir got desperate and began to think about breaking into the man's store to steal the medicine for his wife. 


\section{CASE 2}

A man had been sentenced to prison for 10 years. After one year, however, he escaped from prison, moved to another state, and took on the name of Karim. For eight years he worked hard, and gradually he saved enough money to buy his own business. He was fair to his customers, gave his employees top wages, and gave much of his own profits to charity. Then one day, Puan Salmah, an old neighbour, recognized him as the man who had escaped from prison eight years before and whom the police had been looking for.

\section{CASE 3}

Lim, a senior in high school, wanted to publish a school newspaper for students so that he could express many of his opinions. He wanted to speak out against the use of foreign intervention in international disputes and to complain about some of the school's rules, like the rule of caning pupils in school. When Lim started his newspaper, he asked his principal for permission. The principal said it would be all right if before every publication Lim could turn in all his articles for the principal's approval. Lim agreed and turned in several articles for approval. The principal approved all of them and Lim published two issues of the paper in the next two weeks. But the principal had not expected that the newspaper would receive so much attention. Students were so excited by the paper that they began to organize protests against the caning regulation and other school rules. Angry parents objected to Lim's opinions. They phoned the principal telling him that the newspaper was unpatriotic and should not be published. As a result of the rising excitement, the principal ordered Lim to stop publishing. He gave as a reason that Lim's writings were disruptive to the operation of the school. 